\title{
A review of seventeen years of bank filtration in Brazil: results, benefits and challenges - Part 2: states of Pernambuco and Minas Gerais
}

\section{Revisão de dezessete anos de estudos em filtração em margem no Brasil: resultados, benefícios e desafios - Parte 2: Estados de Pernambuco e Minas Gerais}

\author{
Data de entrada: \\ 04/04/2019 \\ - Data de aprovação: \\ $26 / 05 / 2020$
}

Marcelo Luiz Emmendoerfer ${ }^{1 *}$ | Marcelle Martins ${ }^{2}$ | Bruno Segalla Pizzolatti' | Marcus Bruno Domingues Soares ${ }^{2}$ | Aline Maria Signori' | Maurício Luiz Sens ${ }^{1}$

\section{ORCID ID}

Emmendoerfer ML (D) https://orcid.org/0000-0003-1346-6267

Martins M (D) https://orcid.org/0000-0003-4623-2993

Pizzolatti BS (D) https://orcid.org/0000-0002-2765-7040

\begin{abstract}
Soares MBD (D) https://orcid.org/0000-0002-0857-707X Signori AM (D) https://orcid.org/0000-0003-1416-6258

Sens ML (D) https://orcid.org/0000-0001-5013-4267
\end{abstract}

\section{Abstract}

This work is the second part of "A Review of seventeen years of bank filtration in Brazil: results, benefits, and challenges". Part 2 describes the research on water treatment carried out in the states of Pernambuco (Olinda city, metropolitan region of Recife and region of Garanhuns) and Minas Gerais (Viçosa city). The main benefit of bank filtration (BF) is that it is an alternative way of obtaining a higher quality raw water compared to the traditional water supply methods when local geological conditions are favorable. BF technology highlights other relevant aspects: it may become one of the main water pretreatments in rivers or lakes with sandy sediments; it is possible to obtain quality water in a well up to the first impenetrable layer (30 m deep); the technology removes $100 \%$ of total and fecal coliforms; it may reduce water turbidity at high levels; its pretreatment application may reduce the amount of inputs in the water and, consequently, the generated sludge.

Keywords: Bank Filtration. Water Treatment. Local Geological Conditions. Pretreatment. Impenetrable Layer.

\section{Resumo}

Este trabalho é a segunda parte de "A Review of seventeen years of bankfiltration in Brazil: results, benefits, and challenges". A parte 2 descreve as pesquisas sobre tratamento de água realizadas no estado de Pernambuco (cidade de Olinda, região metropolitana de Recife e região de Garanhuns) e estado de Minas Gerais (cidade de Viçosa). 0 principal benefício da filtração em margem (FM) é ser uma forma alternativa de obtenção de água bruta de melhor qualidade em comparação com os métodos tradicionais de captação de água, quando as condições geológicas locais são favoráveis. A tecnologia de FM destaca outros aspectos relevantes: pode se tornar um dos principais pré-tratamentos de água em rios ou lagos com sedimentos arenosos; é possível obter água de qualidade em poço até a primeira camada impenetrável (30 m de profundidade); a tecnologia remove

\footnotetext{
${ }^{1}$ Universidade Federal de Santa Catarina - Florianópolis - Santa Catarina - Brasil.

2 Universidade Federal de Santa Maria - Campus Frederico Westphalen - Rio Grande do Sul - Brasil.

* Autor correspondente: marcelo.ensagmail.com.
} 
$100 \%$ dos coliformes totais e fecais; pode reduzir a turbidez da água em altos níveis; a aplicação como pré-tratamento pode reduzir a quantidade de insumos na água e, consequentemente, o lodo gerado.

Palavras-chave: Filtração em Margem. Tratamento de água. Condições Geológicas Locais. Pré-tratamento. Camada Impenetrante.

\section{INTRODUCTION}

This second part of "A Review of seventeen years of bank filtration in Brazil: results, benefits, and challenges" (continuation of Part 1 - State of Santa Catarina) consolidates the results obtained over 17 years of studying BF in Brazil to date and draws attention to the main advantages and challenges of this technique; that is, the state of the art at the national level. It illustrates the research performed in the states of Pernambuco and Minas Gerais, where results were compiled in a result matrix, from which tables were created containing physical, chemical, biological, and specific contaminant parameters. For each grouping of results, there was a discussion of the elaborated table.

A bibliographic search was conducted in the national and international databases, which included articles, theses, dissertations, book chapters and course conclusion, totaling 53 (27 in Part 1 and 26 in Part 2) documents that suggested that research on the subject is concentrated in the states of Santa Catarina, Pernambuco and Minas Gerais (Fig. 1).

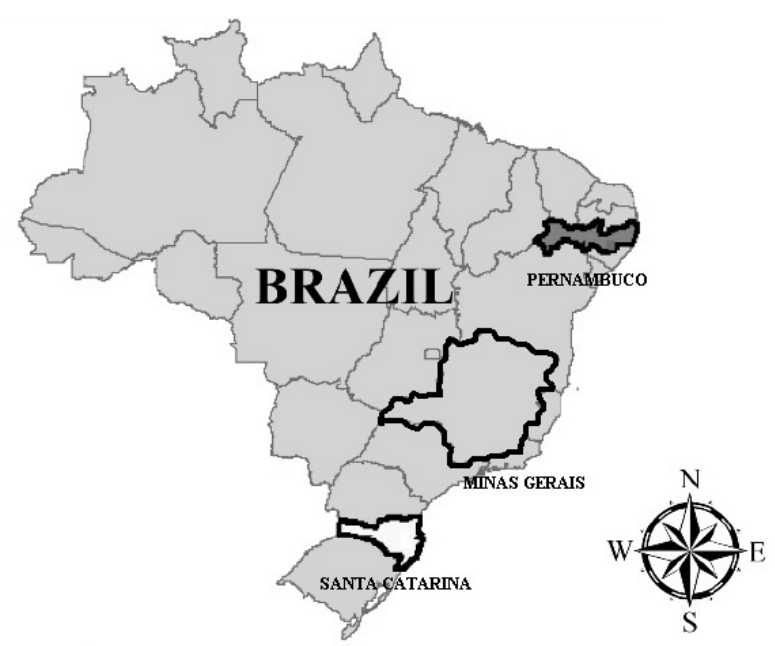

Figure 1 - Map of Brazil indicating the three federative states involved in BF research: Santa Catarina, Minas Gerais and Pernambuco states Source: Authors (Part 1)

\section{STUDIES CARRIED OUT IN THE STATE OF PERNAMBUCO}

$\mathrm{BF}$ as a method of water pre-treatment in the state of Pernambuco (PE) took place in partnership with Companhia Pernambucana de Saneamento (COMPESA). The first experimental station in the state was installed at the Caixa d'Água Elevatory Station, in Olinda, on the banks of the Beberibe River, in the metropolitan region of the city of Recife, Pernambuco (PAIVA, 2009). Other studies in Pernambuco occurred in a semi-arid region in the city of Garanhuns, in the Mundaú Public Supply Reservoir, which has an advanced eutrophication process. The study sites in Pernambuco are shown in Fig. 2. 


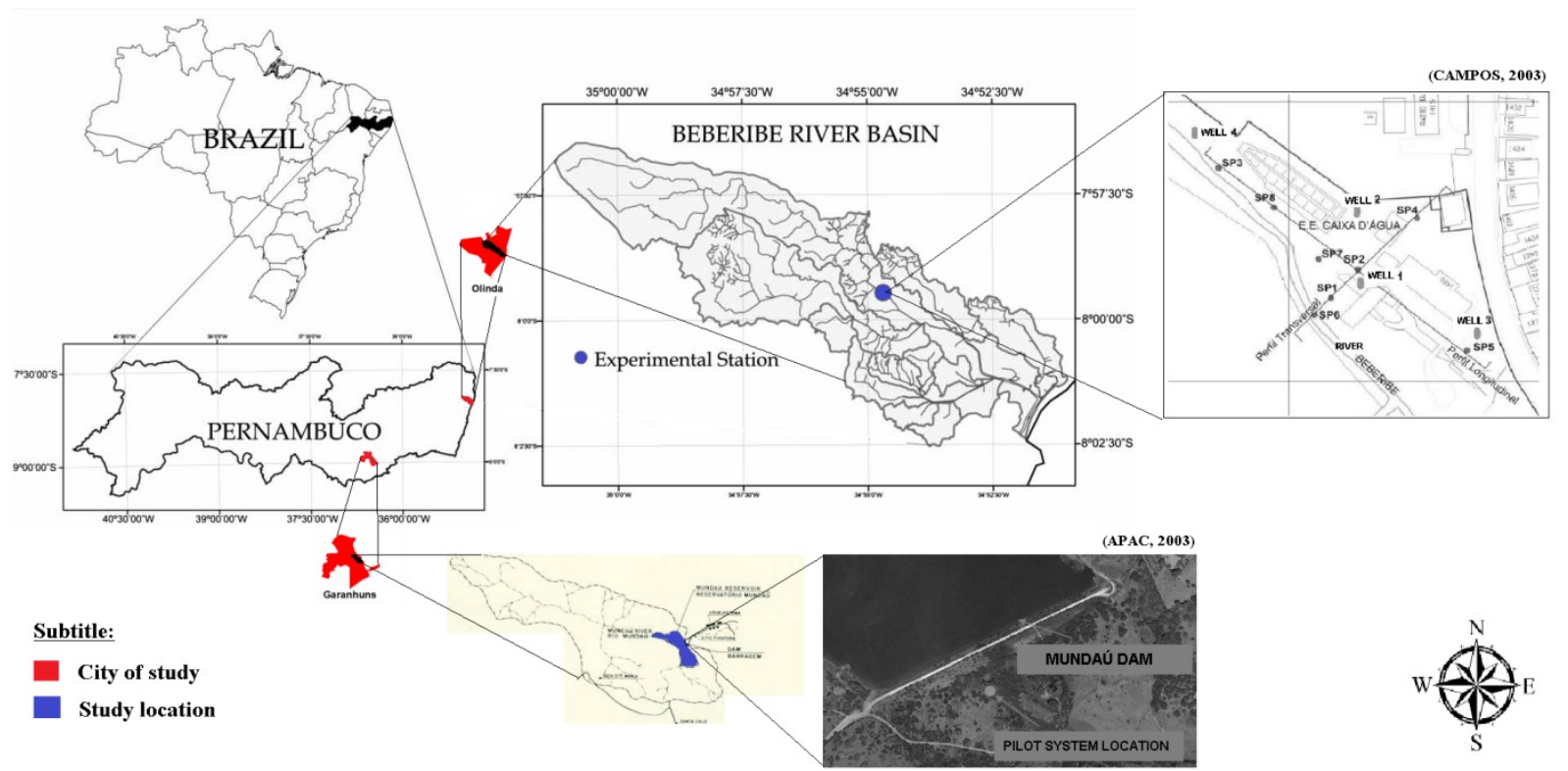

Figure 2 - Study sites for the BF technique in the state of Pernambuco, Brazil Source: Adapted from APAC and Campos (2003)

\subsection{Beberibe River - Olinda (PE) -}

\section{Characterization of the banks of Beberibe River}

The study site of the Beberibe River basin is located between the UTM coordinates of 261228.80 $\mathrm{m} \mathrm{E}$ and $9105854.46 \mathrm{~m} \mathrm{~S}$, zone 25, located in the metropolitan region of Recife, crossing the municipalities of Recife, Olinda and Camaragibe (CAMPOS, 2003). The river has a predominant west-east orientation, with a drainage area of $81 \mathrm{~km}^{2}$. It has a length of around $19 \mathrm{~km}$, from the confluence of the Araça and Pacas rivers to the end of the Atlantic Ocean. In normal periods, the river is narrow, approximately $6 \mathrm{~m}$ wide (PAIVA, 2009).

The study area is located on the COMPESA site, where water is pumped to two treatment stations that serve some neighborhoods in Recife and Olinda (FREITAS, 2018), with the study site situated at the UTM coordinates of 9115500.00 to $9116000.00 \mathrm{~m} \mathrm{E}$ and 289500.00 to $290000.00 \mathrm{~m} \mathrm{~S}$, zone 25 , which is on the border between Olinda and Recife. Even though the region is highly urbanized, it is close to the Ecological Reserves of Mata de Passarinho and Mata Dois Unidos (located in higher quo- tas), which provide an adequate groundwater recharge in the region (PAIVA, 2009).

The researchers' interest in this region was motivated by the fact that, according to data from the monitoring network of the Environment and Water Resources Company of Pernambuco (CPRH), there are high rates of fecal coliform concentration. Moreover, there are difficulties related to intense industrial, urban (domestic sewage, runoff) and agricultural activity, riparian deforestation, construction of highways and bridges, rainwater drainage from highways and dumps, all of which impact the Beberibe watershed (PAIVA et al., 2010).

The project was installed on the banks of the Beberibe River, presenting silt-clay material, which continually grades to sand and then clay with thickness varying between 2 and $5 \mathrm{~m}$. Sequentially, several layers of coarse, medium, and fine sand were found, up to $18 \mathrm{~m}$, where the sandy silt begins and, subsequently, clay. There is also a peat layer under the riverbed (PAIVA, 2009; PAIVA et al., 2010; VERAS, 2011; FREITAS et al., 2012; FREITAS, 2018). 
The granulometric analysis of the riverbank $(0.2$ $\mathrm{m}$ deep) indicated silty-clay sand sediments, with $44 \%$ sand, $29.8 \%$ silt and $24.99 \%$ clay, with $8.46 \%$ of OM. The riverbed sediments $10.3 \mathrm{~m}$ deep) showed characteristics that varied from coarse to very fine sand, composed of a range of $57.95 \%$ to $96.75 \%$ of sand. According to the studies, the amount of OM fluctuated between $0.46 \%$ to $11.1 \%$, which was higher at the bank (VERAS, 2011; ALBUQUEROQUE, 2015; VERAS et al., 2016; FREITAS, 2018).

The riverbed infiltration rates varied between $1 \times 10^{-3} \mathrm{~m} / \mathrm{s}$ and $1.19 \times 10^{-3} \mathrm{~m} / \mathrm{s}$. Freitas (2018) pointed out that the average diameter of the sediments in the first $5 \mathrm{~cm}$ of the hyporrheic zone was approximately $0.067 \mathrm{~mm}$. As it was as much as $10 \mathrm{~cm}$ deep, the sediment had an average diameter of $0.057 \mathrm{~mm}$.

The hyporrheic fauna found in two different points of the Beberibe River is distributed in groups corresponding to rotifers (2\% to $68 \%$ ), nematodes ( $18 \%$ to $41 \%$ ) and annelids ( $14 \%$ to $54 \%), 3 \%$ of which are other taxonomic groups (VERAS et al., 2016; FREITAS, 2018), with local groups as the most representative $(96 \%$ dominance) (ALBUQQUERQQUE, 2015).

\subsubsection{Characterization of the production well surroundings}

Granulometric tests at a depth of 7 to $7.45 \mathrm{~m}$ denoted a composition of $37 \%$ gravel, $23 \%$ coarse sand, $20 \%$ medium sand, $18 \%$ fine sand and $2 \%$ silt and clay. At a depth of 15 to $45 \mathrm{~m}$, the test indicated a marked presence of fine sand (63\%), in addition to medium sand (23\%), clay (10\%) and silt (4\%) (PAIVA, 2009; PAIVA et al., 2010).

The pumping tests showed that there is a hydraulic conductivity in the locale, varying between $1.4 \times 10^{-5}$ and $1.7 \times 10^{-5} \mathrm{~m} / \mathrm{s}$, mainly due to the coarse sand layer identified in the lithological profiles. The hydraulic conductivity of the aquifer measured by piezometers is approximately $3.0 \mathrm{x}$ $10^{-5} \mathrm{~m} / \mathrm{s}$ (PAIVA, 2009; PAIVA et al., 2010).

The production well (P1), $15 \mathrm{~m}$ from the Beberibe River, was built $15 \mathrm{~m}$ deep, 6 inches in diameter, with a filter section between 6 and $13 \mathrm{~m}$. After the flow tests, it stabilized between $12.5 \mathrm{~m}^{3} / \mathrm{h}$ and $12.6 \mathrm{~m}^{3} / \mathrm{h}(3.47$ and $3.5 \mathrm{~L} / \mathrm{s})$, and the potentiometric studies indicated the flow of natural water towards the well, which was intensified during pumping (PAIVA, 2009; FREITAS, 2010; PAIVA et al., 2010; CABRAL et al., 2011; FREITAS et al., 2011 VERAS, 2011; FREITAS et al., 2012; DEMÉTRIO et al., 2013; FREITAS et al., 2017). Nonetheless, the authors found the hydraulic connection between the river, well and aquifer. Santos (2010) was able to confirm this through isotope analyses.

A series of studies was carried out based on P1; however, in 2012, 3 more production wells were installed on site. In relation to the first production well, the new wells were located in the north (P2), southeast (P3) and northwest (P4), as shown in Fig. 3. Each one had characteristics similar to P1, with 6 inches in diameter and $15 \mathrm{~m}$ depth with a filter section between 6 and $12 \mathrm{~m}$. The average flow of the wells was $9.57 \mathrm{~m}^{3} / \mathrm{h}(2.7 \mathrm{~L} / \mathrm{s})$ in $\mathrm{P} 2$, $9.13 \mathrm{~m}^{3} / \mathrm{h}(2.5 \mathrm{~L} / \mathrm{s})$ in $\mathrm{P} 3$ and $9.8 \mathrm{~m}^{3} / \mathrm{h}(2.72 \mathrm{~L} / \mathrm{s})$ in $\mathrm{P} 4$, although the latter well has not yet been studied. In the same way, there was a hydraulic connection between the wells, the aquifer and the shallow source (FREITAS et al., 2012, 2017; FREITAS, 2018).

\subsubsection{Characterization of water quality: physical and chemical parameters}

The following are the compilations of physical, chemical, biological and contaminant parameters analyzed in the BF system on the Beberibe River, through production wells P1, P2 and P3, 
between 2009 and 2018. P2 has not been extensively studied.

Freitas (2018) conducted research on the P2 and P3 well systems, with the location characterization of the facilities, which is mainly maintained by evaluating the hyporrheic zone of the Beberibe River. Thus, the performed water analysis of physical and chemical parameters served as complementary information in the research area. Veras (2011) achieved the parameters analysis at P1 through monitoring records over 6 months, identifying turbidity values less than 1.6 NTU in FW, while RW reached concentrations greater than 140 NTU. Similarly, the apparent color showed maximum levels of about $30 \mathrm{Pt}-\mathrm{Co}$ Units in the FW, in a period of intense rains, while the RW had rates greater than $320 \mathrm{Pt}$ - Co Units. These results have not been tabulated.
Table 1 presents the physical parameters assessed at different times of the BF system operation applied in the Beberibe River by some authors, according to the references in the table.

The P1 studies demonstrate great variation of apparent color and turbidity in the source. However, $\mathrm{BF}$ proved to be quite efficient in its removal. The average removal percentage involves the results obtained by different researchers over time, without obtaining less than $98 \%$ apparent color removal (ALBUQUERQUE, 2015; VERAS et al., 2017), and less than $95 \%$ turbidity removal (PAIVA, 2009; FREITAS, 2010; PAIVA et al., 2010; FREITAS et al., 2012, 2013 and 2017). In the P3 studies by Freitas et al. (2017), they obtained excellent results in removing these two physical parameters as well. An SS removal of $98 \%$ at P1 was also observed (PAIVA, 2009).

Table 1 - Results of the physical parameters obtained in the Beberibe River.

\begin{tabular}{|c|c|c|c|c|}
\hline & $\begin{array}{l}\text { Apparent color } \\
\text { (Pt-Co Units) }\end{array}$ & Turbidity (NTU) & SS (mg/L) & Temperature $\left({ }^{\circ} \mathrm{C}\right)$ \\
\hline Ref. & $\begin{array}{l}\text { (ALBUQUERQUE, 2015; } \\
\text { FREITAS et al., 2017) }\end{array}$ & $\begin{array}{l}\text { ALBUQUERQUE, 2015; } \\
\text { FREITAS, 2010; FREITAS et } \\
\text { al., 2012, 2013, 2017; PAIVA, } \\
\text { 2009; PAIVA et al., 2010) }\end{array}$ & (PAIVA, 2009) & FREITAS et al., 2017) \\
\hline RW & 169 , to 180.3 & 14.3 to 87.62 & 75.27 & 27.6 \\
\hline $\mathrm{FW}(\mathrm{P} 1)$ & 0 to 2.7 & 0.09 to 1.12 & $<1.63$ & 27.3 \\
\hline \multirow[t]{2}{*}{$\%$ average removal } & 99 & 98 & 98 & $\mathbf{x}$ \\
\hline & $\begin{array}{l}\text { Apparent color } \\
\text { (Pt-Co Units) }\end{array}$ & Turbidity (NTU) & SS (mg/L) & Temperature $\left({ }^{\circ} \mathrm{C}\right)$ \\
\hline References & FREITAS et al., 2017) & FREITAS et al., 2017) & FREITAS et al., 2017) & FREITAS et al., 2017) \\
\hline RW & 169.1 & 44 & $x$ & 27.6 \\
\hline FW (P3) & 1.8 & 0.04 & $x$ & 27.5 \\
\hline$\%$ removal & 99 & 100 & $\mathbf{x}$ & $\mathbf{x}$ \\
\hline
\end{tabular}

RW- raw water (source-Beberibe River); FW- filtered water (production wells); NTU- Turbidity Unit; SS- Suspended solids.

Source: Adapted from Paiva (2009); Freitas (2010); Paiva et al. (2010); Freitas et al. (2012 and 2013); Albuquerque (2015) and Freitas et al. (2017)

Regarding the chemical results analyzed in well P1, Table 2 shows a considerable decrease in alkalinity, but a less pronounced alkalinity of bicarbonates, calcium, copper, nickel, manganese and total hardness. In these studies, the removal of $100 \%$ chromium and $96 \%$ total iron stands out. The $\mathrm{pH}$ also showed a small decrease.
In Paiva's et al. (2010) studies at P1, unlike what was observed in Table 2, there was a 2-fold increase in the concentration of manganese. Zinc also varied, with a 1.4-fold increase in $\mathrm{P} 1$ water (PAIVA, 2009) and a 13\% removal in 2010 (FREITAS, 2010) (results not tabulated). The electrical conductivity slightly fluctuated, with a de- 
crease of 4\% (PAIVA, 2009; FREITAS et al., 2017) and a 1.1-fold increase of (FREITAS, 2010; PAIVA et al., 2010; FREITAS et al., 2012). Unlike the results in Table 2, the hardness in Freitas' works had a 1.3-fold increase (FREITAS, 2010; PAIVA et al., 2010; FREITAS et al., 2012). The increase in electrical conductivity and total hardness (FREITAS et al., 2012) was attributed to the leaching of some compounds from the soil or changes in redox conditions.

Table 2 - Results of the chemical parameters obtained in P1.

\begin{tabular}{|c|c|c|c|c|c|c|c|c|c|c|c|}
\hline & $\begin{array}{c}\text { Total } \\
\text { Alc. (mg } \\
\left.\mathrm{CaCO}_{3} / \mathrm{L}\right)\end{array}$ & $\begin{array}{c}\text { Alc. of } \\
\text { bicar. in } \\
\mathrm{CaCO}_{3} \\
\text { (mg/L) }\end{array}$ & $\begin{array}{c}\mathrm{Ca}^{2+} \\
(\mathrm{mg} / \mathrm{L})\end{array}$ & $\begin{array}{c}\text { Total } \\
\text { hardness } \\
(\mathbf{m g} \\
\left.\mathrm{CaCO}_{3} / \mathrm{L}\right)\end{array}$ & $\begin{array}{l}\text { Chlorides } \\
\text { (mg C'-/L) }\end{array}$ & $\mathrm{pH}$ & $\begin{array}{c}\text { Ferro } \\
\text { total } \\
\text { (mg/L) }\end{array}$ & $\begin{array}{c}\mathrm{Mn}^{2+} \\
(\mathrm{mg} / \mathrm{L})\end{array}$ & $\begin{array}{c}\mathrm{Cu}^{+} \\
(\mathrm{mg} / \mathrm{L})\end{array}$ & $\begin{array}{c}\mathrm{Cr}^{3^{+}} \\
(\mathrm{mg} / \mathrm{L})\end{array}$ & $\underset{(\mathrm{mg} / \mathrm{L})}{\mathrm{Ni}^{2+}}$ \\
\hline 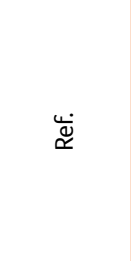 & 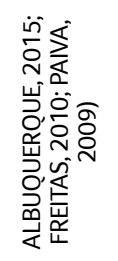 & 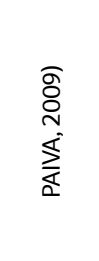 & $\begin{array}{l}\text { ন } \\
\text { ठ্থ } \\
\vdots \\
\vdots \\
\vdots\end{array}$ & 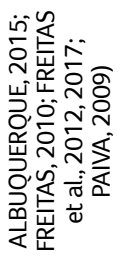 & 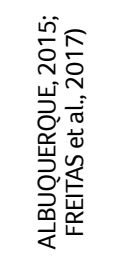 & 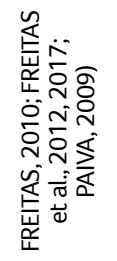 & 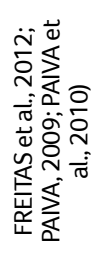 & 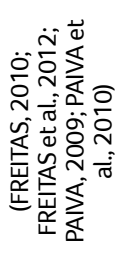 & 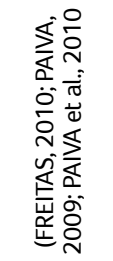 & 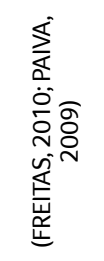 & 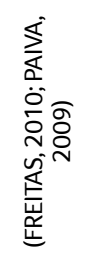 \\
\hline RW & $\begin{array}{c}25.64 \text { to } \\
101.8\end{array}$ & 25.64 & 9.41 & $\begin{array}{c}30.69 \text { to } \\
87.6\end{array}$ & $\begin{array}{c}22.5 \text { to } \\
40.1\end{array}$ & 6.6 to 7.5 & $\begin{array}{c}1.59 \text { to } \\
2.31\end{array}$ & $\begin{array}{c}0.01 \text { to } \\
0.057\end{array}$ & $\begin{array}{c}0.01 \text { to } \\
0.072\end{array}$ & $\begin{array}{c}0.028 \text { to } \\
0.033\end{array}$ & 0.38 \\
\hline FW (P1) & $\begin{array}{c}12.09 \text { to } \\
18.3\end{array}$ & 12.09 & 5.7 & $\begin{array}{c}33.24 \text { to } \\
49.2\end{array}$ & $\begin{array}{c}30.1 \text { to } \\
30.4\end{array}$ & 5.5 to 6.6 & $\begin{array}{c}0.05 \text { to } \\
0.098\end{array}$ & $\begin{array}{c}0.02 \text { to } \\
0.038\end{array}$ & $\begin{array}{c}<0.01 \text { to } \\
0.026\end{array}$ & 0 & 0.31 \\
\hline $\begin{array}{c}\% \text { average } \\
\text { removal }\end{array}$ & 71 & 53 & 40 & 36 & 15 & $x$ & 96 & 30 & 55.6 & 100 & 25 \\
\hline
\end{tabular}

RW- raw water (source-Beberibe River); FW- filtered water (production well).

Source: Adapted from Paiva (2009); Freitas (2010); Paiva et al. (2010); Freitas et al. (2012 and 2013); Albuquerque (2015) and Freitas et al. (2017)

Veras (2011), through monitoring P1 over time, found a decrease in $\mathrm{pH}$, electrical conductivity, total alkalinity and total hardness of filtered water in relation to raw water (results not tabulated).
Table 3 shows an average removal of more than $50 \%$ of all evaluated parameters (ammonia, nitrite, nitrate, BOD and COD), indicating the degradation of the compounds present in RW as it infiltrates the soil. The removal of $100 \%$ nitrites and $90 \%$ ammonia stands out.

Table 3 - Other results of chemical parameters obtained in P1.

\begin{tabular}{|c|c|c|c|c|c|c|}
\hline & $\mathrm{DOC}(\mathrm{mg} / \mathrm{L})$ & $\mathrm{NH}_{3}(\mathrm{mg} / \mathrm{L})$ & $\mathrm{NO}_{2}^{-}(\mathrm{mg} / \mathrm{L})$ & $\mathrm{NO}_{3}^{-}(\mathrm{mg} / \mathrm{L})$ & BOD $(\mathrm{mg} / \mathrm{L})$ & COD (mg/L) \\
\hline Ref. & $\begin{array}{l}\text { (FREITAS et al., } \\
\text { 2012) }\end{array}$ & $\begin{array}{c}\text { (ALBUQUERQUE, } \\
\text { 2015; FREITAS, } \\
\text { 2010; FREITAS et al., } \\
\text { 2012; PAIVA, 2009; } \\
\text { PAIVA et al., 2010) }\end{array}$ & $\begin{array}{c}\text { ALBUQUERQUE, } \\
\text { 2015; FREITAS, } \\
\text { 2010; FREITAS et al., } \\
\text { 2012; PAIVA, 2009; } \\
\text { PAIVA et al., 2010) }\end{array}$ & $\begin{array}{l}\text { ALBUQUERQUE, } \\
\text { 2015; FREITAS, } \\
\text { 2010; FREITAS et al., } \\
\text { 2012; PAIVA, 2009; } \\
\text { PAIVA et al., 2010) }\end{array}$ & $\begin{array}{c}\text { (FREITAS, 2010; } \\
\text { FREITAS et al., 2012; } \\
\text { PAIVA, 2009; PAIVA } \\
\text { et al., 2010) }\end{array}$ & $\begin{array}{l}\text { (FREITAS, 2010; } \\
\text { PAIVA, 2009; PAIVA } \\
\text { et al., 2010) }\end{array}$ \\
\hline RW & 26.8 & 0.29 to 4.81 & 0 to 5.3 & 0.88 to 3.3 & 3.27 to 6.17 & 11 to 27.18 \\
\hline $\mathrm{FW}(\mathrm{P} 1)$ & 9.2 & 0.2 to 0.448 & 0 to 0.005 & 0.003 to 0.51 & 0.81 to 2.43 & 3 to 15.27 \\
\hline$\%$ average removal & 66 & 90 & 100 & 73 & 68 & 58 \\
\hline
\end{tabular}

RW- raw water (source-Beberibe River); FW- filtered water (production well); \% average removal - average removal of the parameter in the FW; DOC - dissolved organic carbon; BOD- Biochemical oxygen demand; COD - Chemical oxygen demand; $\mathrm{NH}_{3}-\mathrm{Ammonia} ; \mathrm{NO}_{2}{ }^{-} \mathrm{Nitrite}^{-} \mathbf{N O}_{3}{ }^{-}-\mathrm{Nitrate}$.

Source: Adapted from Paiva (2009); Freitas (2010); Paiva et al. (2010); Freitas et al. (2012) and Albuquerque (2015)

Despite the oscillations observed in the raw water throughout the monitoring, there was a large removal of nitrogen compounds in the research by Veras (2011), with ammonia, nitrite and nitrate presenting results very close to zero most of the time. 
Table 4 shows the results of some chemical parameters evaluated in P2 and P3. The table highlights the BF's efficiency in removing $97 \%$ of magnesium (FREITAS, 2018). A small decrease in the conductivity of P2 (FREITAS, 2018) and P3 was also observed, oscillating between a decrease of $4.45 \%$ (FREITAS et al., 2017) (A) and an 1.2-fold increase in FW in relation to RW (FREITAS, 2018) (B).

Table 4 - Results of some chemical parameters obtained in P2 and P3.

\begin{tabular}{|c|c|c|c|c|c|c|}
\hline & $\begin{array}{l}\text { Chlorides (mg } \\
\left.\mathrm{Cl}^{-} / \mathrm{L}\right)\end{array}$ & $\begin{array}{c}\text { Electrical } \\
\text { conductivity ( } \mu \mathrm{S} / \\
\mathrm{cm}) \mathrm{A}\end{array}$ & $\begin{array}{c}\text { Electrical } \\
\text { conductivity }(\mu S / \\
\text { cm) B }\end{array}$ & $\begin{array}{c}\text { Total hardness (mg } \\
\left.\mathrm{CaCO}_{3} / \mathrm{L}\right)\end{array}$ & $\mathrm{Mg}^{2+}(\mathrm{mg} / \mathrm{L})$ & $\mathrm{pH}$ \\
\hline Ref. & $\begin{array}{l}\text { (FREITAS et al., } \\
\text { 2017) }\end{array}$ & $\begin{array}{c}\text { (FREITAS et al., } \\
\text { 2017; FREITAS, } \\
\text { 2018) }\end{array}$ & (FREITAS, 2018) & $\begin{array}{l}\text { (FREITAS et al., } \\
\text { 2017) }\end{array}$ & (FREITAS, 2018) & $\begin{array}{c}\text { (FREITAS et al., } \\
\text { 2017; FREITAS, } \\
\text { 2018) }\end{array}$ \\
\hline RW & $x$ & 394.75 & $x$ & $x$ & 3.125 & 6.76 \\
\hline $\mathrm{FW}(\mathrm{P} 2)$ & NA & 345 & $x$ & $x$ & 0.1 & 7.22 \\
\hline$\%$ average removal & $x$ & 13 & $x$ & $\mathbf{x}$ & 97 & $\mathbf{x}$ \\
\hline RW & 22.5 & 247 & 394.75 & 31.3 & 3.125 & 6.6 to 7.2 \\
\hline FW (P3) & 35.4 & 236 & 475.75 & 37.3 & 0.1 & 5.4 to 6.54 \\
\hline$\%$ average removal & $x$ & 4.45 & $\mathbf{x}$ & $x$ & 97 & $\mathbf{x}$ \\
\hline FW/RW & 1.6 & $x$ & 1.2 & 1.2 & $x$ & $x$ \\
\hline
\end{tabular}

RW- raw water (source-Beberibe River); FW- filtered water (production well); FW/RW - increment of the parameter in FW.

Source: Adapted from Freitas et al. (2017) and Freitas (2018)

Freitas et al. (2017) recorded an increase in chlorides and total hardness in P1 and P3 as well as a decrease in electrical conductivity and $\mathrm{pH}$ in both wells. Such changes were related to the degradation of OM, physical-chemical processes and dissolution of compounds during filtration. In addition, a redox potential of $-66.2 \mathrm{mV}$ in P2 and $5.42 \mathrm{mV}$ in P3 was observed (FREITAS, 2018).

\subsubsection{Biological parameters and specific contaminant}

The following tables (Table 5 and Table 6) demonstrate the efficiency of $\mathrm{BF}$ in removing microbiological parameters. It is possible to observe a great variation of total coliforms and $E$. coli in the source with time. However, even in periods of high concentrations ( $\geq 160,000$ ), as in the studies by Freitas et al. (2013 and 2017), the absence of these parameters in the water of the production well was verified. Freitas et al. (2017) also evaluated total coliforms in well P3, obtaining the same result.

Table 5 - Results of some biological parameters evaluated in well P.

\begin{tabular}{|c|c|c|c|}
\hline Parameters & References & Raw water-Beberibe River & Filtered water \\
\hline Cyanobacteria (cells/mL) & (FREITAS, 2010; FREITAS et al., 2012) & $\sim 1,678$ to $\sim 15,286$ & Absent \\
\hline \multirow{5}{*}{ Total coliforms (MPN/100 mL) A } & (FREITAS, 2010) & 1,516 to 48,932 & $<2.0$ \\
\hline & (PAIVA et al., 2010) & $>160,000$ & $<2.0$ \\
\hline & (FREITAS et al., 2012) & 1,516 to 30,804 & Absent \\
\hline & (FREITAS et al., 2013, 2017) & $\geq 1,600$ to $\geq 160,000$ & Absent \\
\hline & (ALBUQUERQUUE, 2015) & $>1,600$ to $>1,160$ & Absent \\
\hline \multirow{5}{*}{ E. coli (MPN/100 mL) } & (FREITAS, 2010) & 300 to 4,220 & Absent \\
\hline & (PAIVA et al., 2010) & $>160,000$ & $<2.0$ \\
\hline & (FREITAS et al., 2012) & 300 to 3,428 & Absent \\
\hline & (FREITAS et al., 2013) & 50,000 to $\geq 160,000$ & Absent \\
\hline & (ALBUQUERQQUE, 2015) & $>60$ to $>1,600$ & Absent \\
\hline
\end{tabular}

Source: Adapted from Freitas (2010); Paiva et al. (2010); Freitas et al. (2012 and 2013); Albuquerque (2015) and Freitas et al. (2017) 
Contrary to the results in Table 5, the monitoring carried out by Veras (2011) in well P1 showed that only $50 \%$ of the samples performed in the well had absent thermotolerant coliforms, with an average presence of $<2 \mathrm{MPN} / 100 \mathrm{~mL}$, which was the lowest concentration of total coliforms.

Another interesting study conducted in wells P1 and $\mathrm{P} 2$ was about the efficiency of BF in removing pathogenic microorganisms from water, such as protozoa and helminths (FREITAS et al., 2013 and 2017), as shown in Table 6. The results found in
RW correspond to the parameter percentage of 16 total samples.

Veras et al. (2017) also verified the BF potential in the removal of drugs. The contaminant found, with the specific constancy in the Beberibe River, was a widely used anti-inflammatory, diclofenac. Contaminant concentrations in RW ranged from 0.029 to $0.055 \mathrm{mg}^{-\mathrm{L}^{-1}}$ in wells $\mathrm{P} 1$ and $\mathrm{P} 2$, results were obtained from 0 to $0.009 \mathrm{mg} \cdot \mathrm{L}^{-1}$, demonstrating that BF has great potential in attenuating this contaminant.

Table 6 - Results of BF studies on the removal of protozoa and helminths found in the Beberibe River.

\begin{tabular}{|c|c|c|c|c|c|c|c|c|c|c|c|c|}
\hline & 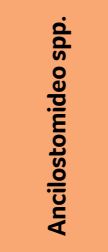 & 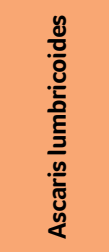 & 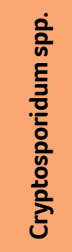 & 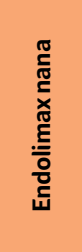 & 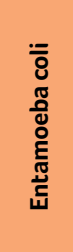 & 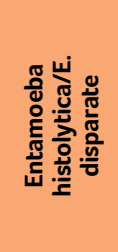 & $\begin{array}{l}\frac{0}{0} \\
\frac{0}{0} \\
\frac{0}{7} \\
\frac{0}{0} \\
\frac{0}{0}\end{array}$ & 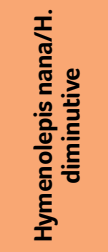 & 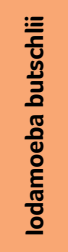 & 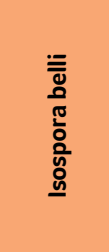 & 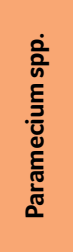 & 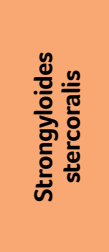 \\
\hline 巡 & 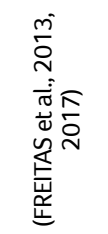 & 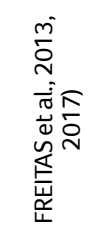 & 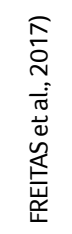 & 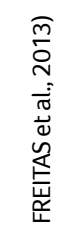 & 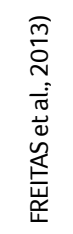 & 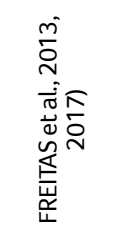 & 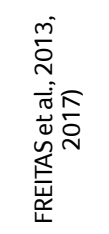 & 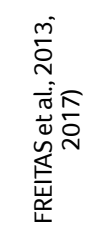 & 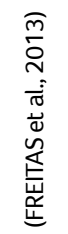 & 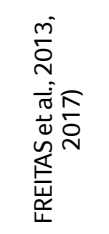 & 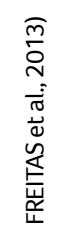 & 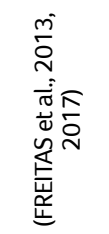 \\
\hline RW & $\begin{array}{c}25 \% \text { and } \\
44 \%\end{array}$ & $\begin{array}{c}100 \% \\
\text { and } 69 \%\end{array}$ & $75 \%$ & $100 \%$ & $50 \%$ & $\begin{array}{c}100 \% \\
\text { and } 50 \%\end{array}$ & $\begin{array}{c}75 \% \text { and } \\
50 \%\end{array}$ & $\begin{array}{c}63 \% \text { and } \\
38 \%\end{array}$ & $88 \%$ & $\begin{array}{c}88 \% \text { and } \\
6 \%\end{array}$ & $88 \%$ & $\begin{array}{c}38 \% \text { and } \\
81 \%\end{array}$ \\
\hline $\mathrm{FW}(\mathrm{P} 1)$ & $A$ & $A$ & $A$ & $A$ & $A$ & $A$ & $A$ & $A$ & $A$ & $A$ & $A$ & $A$ \\
\hline RW & $44 \%$ & $69 \%$ & $75 \%$ & NA & NA & $50 \%$ & $50 \%$ & $38 \%$ & NA & $6 \%$ & NA & $81 \%$ \\
\hline $\mathrm{FW}(\mathrm{P} 3)^{* *}$ & A & A & A & NA & NA & A & A & A & NA & A & NA & $A$ \\
\hline
\end{tabular}

RW- raw water (source-Beberibe River); FW- filtered water (production well); A- Absent; NA- Not Analyzed. * The analyses in P3 were performed in the 2017 studies by Freitas, (FREITAS et al., 2017).

Source: Adapted from Freitas et al. (2013 and 2017)

\subsubsection{Modeling}

Throughout the years that corresponded to the efficiency studies of the BF pilot system applied to the Beberibe River, two different surveys were applied in 2013 (PAIVA, 2013) and 2015 (SANTOS et al., 2015), which focused on mathematical modeling and simulations, as seen in Table 7. 
Table 7 - Synthesis of the models elaborated from field research.

\begin{tabular}{|c|c|c|}
\hline Hypotheses & Scenarios & Main Results \\
\hline \multirow{5}{*}{$\begin{array}{l}\text { Understand the flow processes } \\
\text { between the Beberibe River } \\
\text { and the aquifer system } \\
\text { through pumping induced by a } \\
\text { production well (PAIVA, 2013). }\end{array}$} & \multirow{2}{*}{$\begin{array}{l}\text { Simulation in dry period ( } 0 \\
\text { to } 183 \text { days) with recharge } \\
\text { of } 218 \mathrm{~mm} / \text { year }\end{array}$} & Hydraulic loads (drawdown) reached levels lower than $-2.0 \mathrm{~m}$ around the production well. \\
\hline & & $\begin{array}{l}\text { There was a contribution from the river in its upstream stretch: } 6.41 \mathrm{~m}^{3} / \text { day leaving laterally } \\
\text { from the first layer to the left bank, and } 25.50 \mathrm{~m}^{3} / \text { day vertically. }\end{array}$ \\
\hline & \multirow{3}{*}{$\begin{array}{l}\text { Simulation in rainy season } \\
\text { (183 to } 365 \text { days) with } \\
\text { recharge of } 571 \mathrm{~mm} / \text { year }\end{array}$} & Hydraulic loads (drawdown) reached levels below $-1.7 \mathrm{~m}$ around the production well. \\
\hline & & $\begin{array}{l}\text { The flow occurred in the direction of the river to the production well, in its upstream section, } \\
\text { in the values of } 17.97 \mathrm{~m}^{3} / \text { day, exiting laterally from the first layer to the left bank, } \\
\text { and } 40.93 \mathrm{~m}^{3} / \text { day vertically. }\end{array}$ \\
\hline & & About $20 \%$ of the pumping flow corresponded to the Beberibe River contribution. \\
\hline \multirow{6}{*}{$\begin{array}{l}\text { Develop a numerical model of } \\
\text { the river-aquifer interaction on } \\
\text { the banks of the Beberibe River } \\
\text { and analyze the sensitivity of } \\
\text { conductance and recharge } \\
\text { (SANTOS et al., 2015). }\end{array}$} & \multirow[t]{2}{*}{ Both scenarios } & $\begin{array}{l}\text { The potentiometric maps show that the underground flow occurred in the direction of the } \\
\text { river's flow, from right to left, with an inflow of underground flow in the northwest direction, } \\
\text { due to the existing natural recharge zone. }\end{array}$ \\
\hline & & $\begin{array}{l}\text { Contribution of the river to the aquifer only in the area upstream of the dam, since the } \\
\text { hydraulic load on the river is greater in this stretch. }\end{array}$ \\
\hline & Dry season & Levels less than $-2 \mathrm{~m}$ around the well $-2.3 \mathrm{~m}$. \\
\hline & Wet season & Levels less than $-1.7 \mathrm{~m},-1.6 \mathrm{~m}$ and $-2 \mathrm{~m}$. \\
\hline & \multirow[b]{2}{*}{ Other variations } & Sharp lowering of the groundwater around the production well. \\
\hline & & $\begin{array}{l}\text { The effect on the hydraulic load caused by variations in the conductance values is not } \\
\text { significant. As for the recharge contour condition, due to precipitation and flow from the } \\
\text { recharge zone of the free aquifer, there was a greater sensitivity in variations in hydraulic loads. }\end{array}$ \\
\hline
\end{tabular}

Source: Adapted from Paiva (2013) and Santos et al. (2015)

\subsection{Mundaú Public Supply Reservoir - \\ Guaranhuns (PE) - Characterization of the production well surroundings}

The watershed of the Mundaú River is located in the states of Pernambuco and Alagoas. The Mundaú River rises in the municipality of Garanhuns, a semi-arid region in Pernambuco, where it spans approximately $69 \mathrm{~km}$. The Mundaú River basin, in its entire length, has an area of $4,090.39 \mathrm{~km}^{2}$, of which $2,154.26 \mathrm{~km}^{2}$ is in Pernambuco. The Mundaú basin has three reservoirs, the Mundaú-Guaranhuns Public Supply Reservoir with a capacity of $1,968,600 \mathrm{~m}^{3}$ (APAC).

The $\mathrm{BF}$ production well was built on land that belongs to COMPESA, at the UTM coordinates of $9016346.00 \mathrm{~m} \mathrm{E}$ and $775746.00 \mathrm{~m} \mathrm{~S}$, zone 24 (SANTOS et al., 2011 and 2014; GUEDES et al., 2018). This dam is one that is responsible for the water supply in that municipality and was chosen for this study because it presents frequent blooms of cyanobacteria and receives water effluents from the municipality. The water flows from the body and base of the dam to the production well in a natural way (SANTOS et al., 2011).
To implement the production well, it was decided to change the soil, building two trenches parallel to the well, $10 \mathrm{~m}$ long, $1 \mathrm{~m}$ wide and 1 $m$ deep, with a total capacity of $10 \mathrm{~m}^{3}$, in order to improve the water collection captured by the well as the region has very shallow soil layers, which could harm the BF system (SANTOS et al., 2011 and 2014; GUEDES et al., 2018). Both trenches were filled with medium and coarse sand (diameter between 0.5 and $2.0 \mathrm{~mm}$ ), generating high permeability.

The production well was built $38 \mathrm{~m}$ from the base of the dam, with a depth of $2.5 \mathrm{~m}$ and a diameter of $1 \mathrm{~m}$. The two trenches were located $4 \mathrm{~m}$ away from the well in the center (SANTOS et al., 2011 and 2014; GUEDES et al., 2018). The system was operated with intermittent pumping, with the applied flow varying throughout the studies.

The granulometry tests carried out with material collected up to $1 \mathrm{~m}$ deep showed medium sand (32\%), fine sand (28\%), clay $(21.5 \%)$, silt $(12 \%)$, coarse sand (5\%) and gravel (1.4\%) in its composition. In the first depth of $2.5 \mathrm{~m}$, there was a higher occurrence of fine sand (36\%), clay (24\%), 
medium sand (19\%), silt (14\%), coarse sand (5\%) and gravel (2.5\%) (SANTOS et al., 2011).

\subsubsection{Characterization of water quality: physical and chemical parameters}

Santos et al. (2011) were the pioneers in research involving the system applied in the Mundaú Reservoir, with a flow rate of $1.37 \mathrm{~m}^{3} / \mathrm{h}(0.38 \mathrm{~L} / \mathrm{s})$. As seen in Table 7, the technology was efficient in removing turbidity. It also showed a considerable decrease in $\mathrm{pH}$ ( $2.21 \mathrm{pH}$ units) and a $48 \%$ decrease in DO. The influencing factors in the aforementioned parameters are based on the OM degradation that occurs during the filtration process (SANTOS et al., 2011; GUEDES et al., 2018).
The authors pointed out the influence of groundwater on the resulting electrical conductivity, considering that the water from the dam possibly receives an increase in salinity, and the sediments do not have the necessary capacity to retain salts. The high electrical conductivity was presented as a factor characteristic of shallow aquifers, and, considering the lesser depth of the well, it was assumed that there is greater dissolution of salts in the medium (SANTOS et al., 2011).

The analysis of total iron, in turn, was the object of study by Guedes et al. (2018), through a flow of $0.53 \mathrm{~m}^{3} / \mathrm{h}(0.15 \mathrm{~L} / \mathrm{s})$. It is observed in Table 8 that there was an increase in FW of 100 times in relation to RW.

Table 8 - Physical and chemical parameters obtained in BF studies in the Mundaú Reservoir.

\begin{tabular}{|c|c|c|c|c|c|c|}
\hline & Turbidity (NTU) & Temp. $\left({ }^{\circ} \mathrm{C}\right)$ & $\mathrm{pH}$ & $\begin{array}{l}\text { Electrical } \\
\text { conductivity } \\
(\mu S / \mathrm{cm})\end{array}$ & $\mathrm{DO}(\mathrm{mg} / \mathrm{L})$ & Total iron $(\mathrm{mg} / \mathrm{L})$ \\
\hline Ref. & $\begin{array}{c}\text { (GUEDES et al., } \\
\text { 2018; SANTOS et al., } \\
\text { 2011) }\end{array}$ & $\begin{array}{l}\text { (SANTOS et al., } \\
\text { 2011) }\end{array}$ & $\begin{array}{l}\text { GUEDES et al., 2018; } \\
\text { SANTOS et al., 2011) }\end{array}$ & $\begin{array}{l}\text { (SANTOS et al., } \\
\text { 2011) }\end{array}$ & $\begin{array}{l}\text { GUEDES et al., 2018; } \\
\text { SANTOS et al., 2011) }\end{array}$ & $\begin{array}{c}\text { (GUEDES et al., } \\
\text { 2018) }\end{array}$ \\
\hline RW & 27.32 to 44.1 & 28.24 & 8.46 to 8.5 & 586.6 & 7.2 to 8.2 & 0.3 \\
\hline FW & 13.3 to 14.2 & 24.88 & 6.25 to 6 & 1112.2 & 3.58 to 4.4 & 30.1 \\
\hline$\%$ average removal & 61 & $\mathbf{x}$ & $\mathbf{x}$ & $x$ & 48 & $\mathbf{x}$ \\
\hline FW/RW & $x$ & $x$ & $x$ & 1.9 & $x$ & 100 \\
\hline
\end{tabular}

RW- raw water (Mundaú Reservoir); FW- filtered water (production well); FW / RW - increment of the parameter in the FW; NTU- Turbidity Unit; DO- Dissolved oxygen.

Source: Adapted from Santos et al. (2011) and Guedes et al. (2018)

Applying a lower flow rate than those from their studies in $2011\left(0.24 \mathrm{~m}^{3} / \mathrm{h}(0.07 \mathrm{~L} / \mathrm{s})\right.$ and 2014, Santos et al. (2014) obtained results that indicated turbidity removal, decreased $\mathrm{pH}$ and $\mathrm{DO}$, in addition to increased electrical conductivity, similar to previous studies. However, the authors included the analysis of the iron parameter, and the total concentrations found in the FW corresponded to levels of up to $46 \mathrm{mg} / \mathrm{L}$, while in the raw water there was a close variation to zero, a result even greater than that found by Guedes et al. (2018). The authors still cited the existence of cyanobacteria in the reservoir water but did not identify their presence in filtered water.

\section{LAGOA UFV LAKE- VIÇOSA (MG)}

Viçosa is a municipality in the southern region of the state of Minas Gerais (MG). The BF system was installed in a microbasin located on the premises of the Federal University of Viçosa (ROCHA, 2015; ROCHA and MARQUES, 2016 and 2018) between the UTM coordinates of 722976.32 $\mathrm{m} \mathrm{E}$ and $720336.30 \mathrm{~m} \mathrm{E}, 7703120.40 \mathrm{~m} \mathrm{~S}$ and $7700386.54 \mathrm{~m} \mathrm{~S}$, zone 23S, as shown in Fig. 3. The pilot project was implemented in the experimental field of Prof. Diogo Alves de Mello, in the period between May/2013 and October/2013 (ROCHA, 2015). 


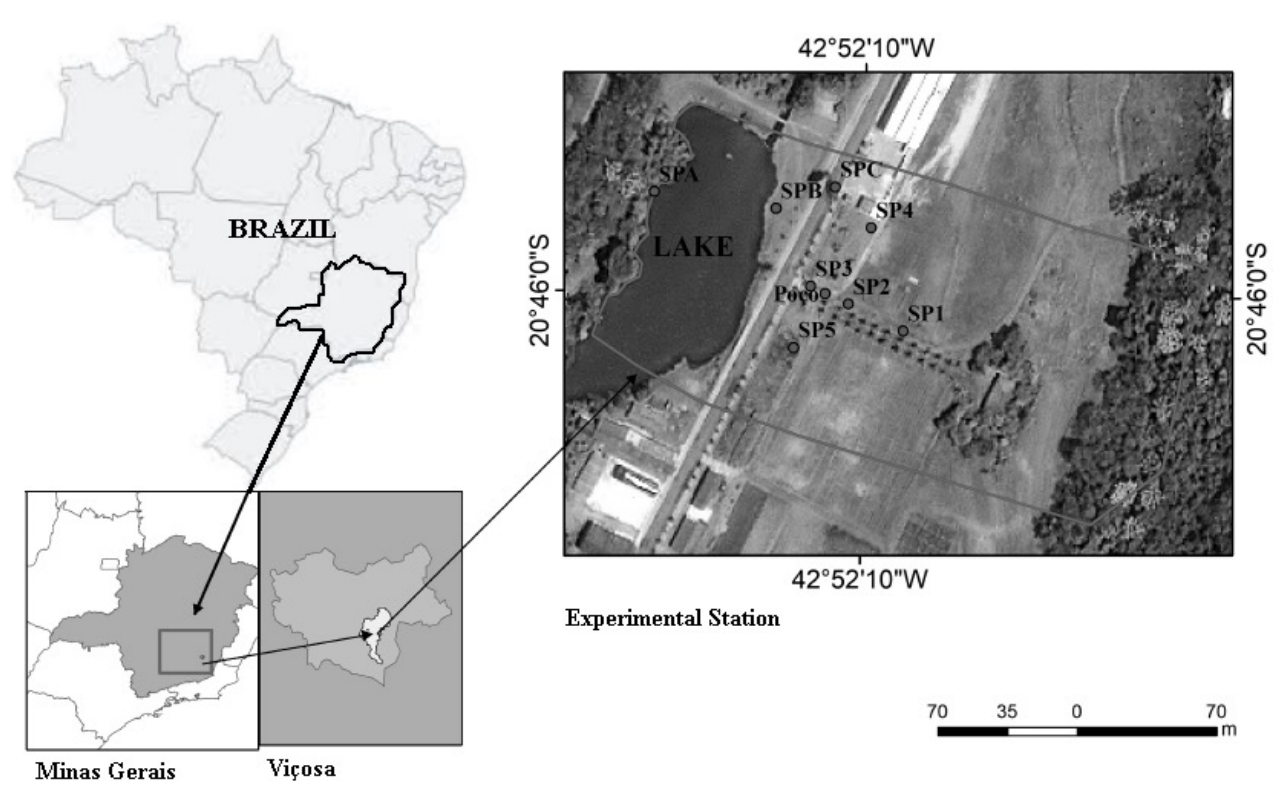

Figure 3 - Location map of the study area - State of Minas Gerais Source: Adapted from Rocha (2015)

\subsection{Characterization of the production well surroundings}

The facilities near the lake had a geomechanical PVC production well 4 inches in diameter and 25 $\mathrm{m}$ deep. In the first $4 \mathrm{~m}$ of depth, soil with silt-clay texture was followed by soil with silt-sand texture, up to $25 \mathrm{~m}$, where the rocky top begins (ROCHA, 2015; ROCHA and MARQUES, 2016 and 2018).

The pumping was configured as intermittent, with a flow variation between $4.5 \mathrm{~m}^{3} / \mathrm{h}$ and $6.1 \mathrm{~m}^{3} / \mathrm{h}$ (1.25 L/s and $1.7 \mathrm{~L} / \mathrm{s})$. In addition, transmissivity values $(T)$ equal to $1.0 \times 10^{-3} \mathrm{~m}^{2} / \mathrm{s}$ and hydraulic conductivity (K) of $5.0 \times 10^{-5} \mathrm{~m} / \mathrm{s}$ were obtained, with potentiometric results indicating the natural flow of the aquifer towards the lake, passing through the production well. The travel time was identified as at least 85 days, with water passage speed through the porous medium of $0.41 \mathrm{~m} / \mathrm{d}$ (ROCHA, 2015; ROCHA and MARQUES, 2016 and 2018).

\subsection{Characterization of water quality: physical, chemical and biological parameters}

Rocha's experiments included the analysis of the basic parameters of the water quality of the lake and the installed production well, as seen in Table 9 (ROCHA, 2015).

It was possible to verify a $39 \%$ reduction in turbidity in the production well, as well as $\mathrm{pH}$, phosphates, DO, BOD and complete removal of $E$. coli. Such aspects show the degradation activity that occurs during the filtration process at the site. The decrease of $1.06 \mathrm{pH}$ unit was attributed to the decomposition of organic matter, which in turn gives rise to organic acids responsible for the decreased $\mathrm{pH}$. The increased temperature was considered a natural aspect of the process since it is influenced by the composition of the area. 
Table 9 - Results of the parameters obtained at the UFV lake in 2015.

\begin{tabular}{|c|c|c|c|c|c|c|c|}
\hline & Turbidity (NTU) & $\mathbf{p H}$ & Temp. $\left.\mathbf{(}^{\circ} \mathbf{C}\right)$ & $\begin{array}{c}\text { Phosphates } \\
\text { (mg/L) }\end{array}$ & DO (mg 02/L) & BOD (mg/L) & $\begin{array}{c}\text { E. coli (MPN/100 } \\
\mathbf{m L})\end{array}$ \\
\hline RW & 9.24 & 6.19 & 22.62 & 0.07 & 6.1 & 4.48 & 2114 \\
\hline FW & 5.66 & 5.13 & 23.22 & 0.03 & 5.2 & 1.87 & A. \\
\hline $\begin{array}{c}\text { \% average } \\
\text { removal }\end{array}$ & $\mathbf{3 9}$ & $\mathbf{x}$ & $\mathbf{x}$ & $\mathbf{5 7}$ & $\mathbf{1 5}$ & $\mathbf{5 8}$ & $\mathbf{1 0 0}$ \\
\hline
\end{tabular}

RW- raw water (source-UFV Lake); FW- filtered water (production well); NTU- Turbidity Unit; DO- dissolved oxygen; BOD - biochemical demand for oxygen; MPN- most probable number.

Source: Adapted from Rocha (2015)

\subsection{Modeling}

Rocha (2015) and Rocha and Marques (2018) addressed aspects of the hypothesis modeling around the system installed at the UFV lake, such as the identification of the underground flow and possible configurations of filtered water exploitation, according to Table 10.

Table 10 - Synthesis of the models elaborated from field research.

\begin{tabular}{|c|c|c|}
\hline Hypotheses & Scenarios & Main Results \\
\hline $\begin{array}{c}\text { Understand the flow shape of } \\
\text { the aquifer at the site of the BF } \\
\text { system and evaluate variations } \\
\text { in flow and pumping during } \\
\text { periods of drought. }\end{array}$ & $\begin{array}{c}\text { Simulations with 1,5 and } \\
10 \text { years, flow variation, } \\
\text { pumping variation and } \\
\text { allocation of an extra well. }\end{array}$ & $\begin{array}{c}\text { The flow is horizontal and goes towards the lake, passing through the production system, } \\
\text { besides, even in dry periods, the system has available water for pumping. }\end{array}$ \\
\cline { 2 - 3 } & Exploitable flow rates vary up to $38 \mathrm{~m}^{3} / \mathrm{h}(10.55 \mathrm{~L} / \mathrm{s})$. \\
\hline
\end{tabular}

Source: Adapted from Rocha (2015) and Rocha and Marques (2018)

\section{FINAL CONSIDERATIONS}

The following includes the considerations of all the data collected to compose this review (part 1 and part 2), contemplating the three states that carried out research in the area.

The turbidity removal is quite pronounced in $\mathrm{BF}$, considering that a large part of what is suspended in the source is retained in the filtering medium; that is, on its bank. In almost all studies cited, the removal value reached $100 \%$, except in the city of Ituporanga (aquaculture lake), Mundaú (reservoir in the city of Guaranhuns) and in the city of Viçosa. In these three cases, there was the presence of granular material of large diameter in the soil (gravel, pebble, rock), which may have caused this low reduction (Mundaú and Viçosa) or even increase (Ituporanga). Long periods of rain can also impair the reduction of physical parameters.
Regarding the apparent color, due to the turbidity removal through the soil, its removal was also very high, with the exception of Ituporanga, where there was an increased apparent color, likely for the same reason mentioned above. The true color tends to be very similar to the source. Factors of distance from the well in relation to the source, soil composition and the pumping flow of the well are very relevant to obtain the highest removal value. Low removal of physical parameters was observed during periods with large volumes of rainfall, which resulted in compound leaching, such as organic matter and colloidal materials.

The increased flow can be beneficial from the standpoint of the volume of water pumped. On the other hand, it can bring a greater contribution from the aquifer and, thereby, an increase of undesirable chemical elements ( $\mathrm{Fe}, \mathrm{Mn}, \mathrm{Al}, \mathrm{F}$, among others) contained in the soil. Therefore, 
the increased flow should always be monitored to find the ideal point between flow $x$ quality, thus, making the most of this technology.

In some studies, the results of total organic carbon (TOC) and dissolved oxygen (DO) had a decrease of around $50 \%$ and lower values in others. Its reduction is directly linked to the water quality of the source and the presence of organic matter (OM) in the soil. Studies have found that there is a simple reduction or the permanence of a value similar to that of the source with a slight increase.

In practically all of the research, we observed that the values of conductivity, total hardness and alkalinity increased after BF, which was attributed to the processes of erosion and dissolution of the materials when the water passes underground, as well as fields. The $\mathrm{pH}$, in most studies, decreases after BF, probably due to the presence of some acidic species in the soil. When such species are not found in the soil, the $\mathrm{pH}$ tends to be similar to that of the source.

Regarding total and fecal coliforms (E. Coli), the technology, as it is put into operation, may appear at the beginning of the pumping (first days); afterwards, the research indicates $100 \%$ removal or close to this value. Other microbiological parameters studied as well as other specific contaminants were significantly reduced (toxins, pesticides and drugs). This fact can be linked to the travel time between source and well. This travel time is determined by the distance between the source and the well and its flow. Likewise, the study of the flow variation can bring about the optimization of the removal of these parameters.

Salinity was not considered as a parameter in any of the studies, despite being an important parameter for the quality of drinking water, especially in Northeast Brazil. Obviously, in shallow wells, the concentration of salinity does not tend to be high, but in studies close to the sea this parameter must be analyzed when the intention is to use
BF for a real supply situation, in order to fit the values in current legislation.

The main benefit of $\mathrm{BF}$ is that it is an alternative way to obtain better quality raw water compared to traditional water supply methods when soil conditions are favorable. BF technology highlights other relevant aspects: it may become one of the main water pretreatments in rivers or lakes with sandy sediments; it is possible to obtain quality water in a well up to the first impenetrable layer; the technology removes $100 \%$ of total and fecal coliforms; it may reduce water turbidity at high levels; the application as pretreatment may reduce the amount of inputs in the water and consequently, the generated sludge.

In summary, for public supply systems, the big challenge in Brazil is to apply BF as a pre-treatment in already consolidated situations, that is, in systems in operation (water treatment plants), which can make the quality of raw water reach the beginning of treatment with the same standards (or better) as when the current treatment systems were conceived, causing them to have a longer useful life or even receive a greater flow.

Finally, after years of research in Brazil, BF provides well-trained professionals another way to obtain quality water, proving that it is even possible to acquire with a shallow well (up to $30 \mathrm{~m}$ ). Furthermore, specialists in water treatment can consider that better quality raw water is achievable by simplifying the treatment process instead of designing more treatment steps. The fact remains that BF unites areas of knowledge hitherto: geology, chemistry, and biology, which are usually treated in isolation, making the technology increasingly elucidated and widespread.

\section{AUTHORS' CONTRIBUTION}

All authors worked equally in the preparation of this scientific article. 


\section{REFERENCES}

ALBUQUERQQUE, T. B. V. Caracterização física e biológica da zona hiporreica na interação Rio-Aquífero no Rio Beberibe Pernambuco. Thesis (Doctorate in Civil Engineering), Universidade Federal de Pernambuco-UFPE. p. 166, Recife-PE, 2015.

APAC, AGÊNCIA PERNAMBUCANA DE ÁGUAS E CLIMA. Bacias Hidrográficas: Bacia do Rio Mundaú. Available at: http:// www.apac.pe.gov.br/pagina.php?page_id=5\&subpage_id=19. Accessed in: 07 Dec. 2019

CABRAL, J. J. S. P.; FREITAS, D. A.; PAIVA, A. L. R.; and VERAS, T. B. Bankfiltration for water quality improvement in Beberibe River, Recife Metropolitan Region. 2011. Available at: https://iwra. org/member/congress/resource/PAP00-5708.pdf. Acessado em: $11 / 08 / 2019$

CAMPOS, H. L. Processo histórico de gestão na Bacia Hidrográfica do Rio Beberibe (PE): Uma retrospectiva. Thesis (Doctorate) Instituto de Geociências, Universidade Federal do Rio de Janeiro- UFRJ. p. 226, Rio de Janeiro, 2003.

DEMÉTRIO, J. G. A.; PAIVA, A. L. R.; FREITAS, D. A.; BATISTA, A. G. S. B.; and CABRAL, J. J. S. P. Características hidrogeológicas das aluviões do Rio Beberibe na área da bateria de poços no Bairro de Caixa d'Água, Olinda-PE. Águas Subterrâneas, 2013. 27 (3): p. 111-126. https://doi.org/10.14295/ras.v27i3.27411

FREITAS, D. A.; CABRAL, J. J. S. P.; PAIVA, A. L. R.; and VERAS, T. $B$. Influência da zona ripária e da zona hiporreica na interação dos aquíferos com os mananciais de superfície. In: XIX Simpósio Brasileiro de Recursos Hídricos. 2011. Maceió-AL. Anais...

FREITAS, D. A.; CABRAL, J. J. S. P.; ROCHA, F. J. S; PAIVA, A. L. R.; and ALBUQUERQQUE, T. B. V. Uso da técnica de filtração em margem no Rio Beberibe-PE para remoção de microorganismos patogênicos. In:XX Simpósio Brasileiro de Recursos Hídricos, Bento GonçalvesRS. 2013. Anais...

FREITAS, D. A. P.; CABRAL, J. J. S.; ROCHA, F. J.; PAIVA A. L.; SENS M. L.; and VERAS, T. Cryptosporidium spp. and Giardia spp. removal by bank filtration at Beberibe River, Brazil. River Research Applications, 2017. 33 (7): p. 1079-1087. https://doi. org/10.1002/rra.3151

FREITAS, D. A. 0 emprego da técnica de filtração em margem para tratamento de água no Rio Beberibe, região metropolitana do Recife. Dissertation (Master in Civil Engineering), Universidade Federal de Pernambuco-UFPE. p. 148, Recife-PE, 2010.

FREITAS, D. A.; CABRAL, J. J. S. P.; PAIVA, A. L. R.; and MOLICA, R. J. R. Application of bank filtration technology for water quality improvement in a warm climate: a case study at Beberibe River in Brazil. Journal ofWater Supply: Research and Technology-AQUA, 2012. 61 (5): p. 319. https://doi.org/10.2166/aqua.2012.097

FREITAS, J. B. A. Caracterização da zona hiporreica no trecho médio do Rio Beberibe considerando aspectos biológicos e sedimentológicos. Dissertation (Master in Civil Engineering), Universidade Federal de Pernambuco-UFPE. p. 146, Recife-PE, 2018.

GUEDES, T. L.; MICHELAN, D. C. G. S.; LEAL, L. L.; PAIVA, A. L. R.; BURGARDT, T.; CABRAL, J. J. S. P.; DALSASSO, R. L.; and SENS, M. L. Occurrence of iron in bank filtration wells: case studies in Ituporanga (SC) and Garanhuns (PE). Desalination and Water Treatment, 2018. 101: p. 170-177. https://doi.org/10.5004/ dwt.2018.21764

PAIVA, A. L. R. 0 processo de filtração em margem e um estudo de caso no Rio Beberibe. Thesis (Doctorate in Civil Engineering), Universidade Federal de Pernambuco - UFPE,. p. 171, Recife-PE, 2009.

PAIVA, A. L. R.; CABRAL, J. J. S. P.; DEMÉTRIO, J. G. A.; and SOBRAL, M. C. M. Filtração em margem para indução de recarga e melhoria da qualidade de água- Estudo de caso: Rio Beberibe. Águas Subterrâneas, 2010. 24 (1): p. 103-114. https://doi. org/10.14295/ras.v24i1.20094

PAIVA, A. L. R.; CABRAL, J. J. S. P.; DEMÉTRIO, J. G. A.; and FREITAS, D. A. Interação Rio-Aquífero com Bombeamento em um Poço Próximo ao Rio num Sistema de Filtração em Margem. RBRH Revista Brasileira de Recursos Hídricos, 2013. 18 (1): p. 235 247. https://doi.org/10.21168/rbrh.v18n1.p235-247

ROCHA, S. F. Implantação de um sistema de filtração em margem e avaliação hidrogeológica da interação Lago-Aquífero. Thesis (Doctorate in Civil Engineering), Universidade Federal de Viçosa. p. 130, Viçosa-MG, 2015.

ROCHA, S. F.; and MARQQUES, E. G. Caracterização Hidrogeológica de um Sistema de Filtração em Margem de Lago Hydrogeological Characterization of a Lake Bank Filtration System. Anuário do Instituto de Geociências, 2016. 39: p. 131. https://doi. org/10.11137/2016_1_133_141

ROCHA, S. F. and MARQUES, E. G. Three-dimensional modeling of steady-state flow in Lake bank filtration - Brazil. Water Science and Technology: Water Supply, 2018. 19: p. https://doi. org/10.2166/ws.2018.052

SANTOS, L. L.; CABRAL, J. J. S. P; PAIVA, A. L. R.; and ROSÁRIO, M. Utilização de Isótopos estáveis para análise da interação da água superficial e água subterrânea num estudo de Filtração em Margem. In:XVI Congresso Brasileiro de águas Subterrâneas e XVII Encontro Nacional de Perfuradores de Poços. 2010. São Luis - MA. Anais...

SANTOS, L. L.; BARROS, T. H. S.; CABRAL, J. J. S. P.; and MELO, R. T. Aplicação da tecnologia de filtração em margens para redução ou eliminação de contaminantes físico-químicos na região semiárida de Pernambuco. In: XIX Simpósio Brasileiro de Recursos Hídricos. 2011. Maceió-AL. Anais...

SANTOS, L. L.; CABRAL, J. J. S. P.; CIRILO, J. A.; FREITAS, D. A., and SENS, M. L. Aplicação da tecnologia de filtração em margem para população difusa no Semiárido Pernambucano. RBRH - Revista 
Brasileira de Recursos Hídricos, 2014. 19 (4): p. 49-58. https:// doi.org/10.21168/rbrh.v19n4.p49-58

SANTOS, L. L.; CABRAL, J. J. S. P.; and MELO, R. T. Aplicação da técnica de filtração em margens em um reservatório eutrofizado no semi-árido nordestino. Available at: https:// iwra.org/member/congress/resource/PAP00-5735.pdf. Accessed in: 11/08/19. XIX SIMPÓSIO BRASILEIRO DE RECURSOS HÍDRICOS, Maceió, Setembro de 2011. Anais...

SANTOS, W. J. S.; MONTEIRO, R. V. A.; and PAIVA, A. L. R. Modelagem numérica da interação Rio Aquífero: estudo de caso - Rio Beberibe. In: XXIIIConic / VII Coniti / IV Enic. 2015. Universidade Federal de Pernambuco. Anais...

VERAS, T. B.; CABRAL, J. J. S. P.; PAIVA, A. L. R.; DUARTE, M. M. B.; and ZAIDAN, L. E. M. C. A. A filtração em margem na remoção de fármacos: Estudo de caso Rio Beberibe - PE, Brasil. Faculdade de Engenharia da Universidade do Porto In: $13^{\circ}$ Simpósio de Hidráulica e Recursos Hídricos dos Países de Língua Portuguesa Porto, 2017. Anais...

VERAS, T. B. Análise da interação Rio-Aquífero na zona hiporreica para a tecnologia de filtração em margem: estudo de caso no Rio Beberibe-PE. Dissertation (Master in Civil Engineering), Universidade Federal de Pernambuco- UFPE. p. 136, Recife-PE, 2011.

VERAS, T. B.; CABRAL, J.J. S. P.; PAIVA, A. L. R.; BARCELLOS, R. L.; and SANTOS, L. L. Vertical hydraulic gradient research in hyporheic zone of Beberibe river in Pernambuco State (Brazil). Revista Brasileira de Recursos Hídricos, 2016. 21 (4): p. 674-684. https:// doi.org/10.1590/2318-0331.011615153 